\title{
Do earthworms ( $D$. veneta) influence plant-available water in technogenic soil-like substrate from bricks and compost?
}

\author{
Susanne Ulrich ${ }^{1} \cdot$ Moreen Willaredt $^{2} \cdot$ Thomas Nehls $^{2} \cdot$ Loes van Schaik ${ }^{3}$
}

Received: 9 December 2019 / Accepted: 1 September 2020 / Published online: 15 September 2020

(C) The Author(s) 2020

\begin{abstract}
Purpose Topsoil and peat are often taken from intact rural ecosystems to supply the urban demand for fertile soils and soillike substrates. One way of reducing this exploitation is to recycle suitable urban wastes to produce Technosols and technogenic soil-like substrates. In this study, we investigate the role earthworms can play in impacting the hydraulic properties of such a soil-like substrate.

Materials and methods In a 4-month microcosm experiment, the influence of the earthworm species $D$. veneta on the hydraulic properties of brick-compost mixture was examined. Of the ten boxes filled with ca. $11 \mathrm{dm}^{3}$ of ground bricks $\left(0.7 \mathrm{~cm}^{3} \mathrm{~cm}^{-3}\right)$ and green waste compost $\left(0.3 \mathrm{~cm}^{3} \mathrm{~cm}^{-3}\right)$, five contained earthworms (W-boxes) and the remaining five were used as controls (Cboxes). The substrate was periodically irrigated and the weight of the boxes and of the drained water was monitored. At the same time, images were taken from the front of the boxes to quantify the activity of the earthworms by image analysis and soil aggregation was studied with micrographs. Before and after the experiment, water retention curves were determined from disturbed samples of the substrate using the simplified evaporation method.

Results and discussion After 6 weeks, differences between the C- and the W-boxes were evident. Micrographs showed brickcompost aggregates only for the substrates processed by earthworms. The earthworm activity leads to reduced evaporation and an increased water content in the respective microcosms. The effect persists even after disturbing the substrate. The proportion of plant-available soil water is about $0.02 \mathrm{~cm}^{3} \mathrm{~cm}^{-3}$ higher for the substrate processed by earthworms $\left(0.250 \pm 0.009 \mathrm{~cm}^{3} \mathrm{~cm}^{-3}\right)$ compared with the control $\left(0.230 \pm 0.008 \mathrm{~cm}^{3} \mathrm{~cm}^{-3}\right)$.

Conclusions This study shows that earthworms are capable of ingesting and processing crushed bricks together with compost. The earthworms produced aggregates which persisted after disturbance and had a positive influence on the water retention capacity of such a soil-like substrate constructed from waste.
\end{abstract}

Keywords Brick-compost mixture $\cdot$ Earthworms $\cdot$ Microcosms $\cdot$ Soil-like substrate $\cdot$ Water retention $\cdot$ Technosol

Responsible editor: Jean Louis Morel

Thomas Nehls

Thomas.nehls@tu-berlin.de

1 Soil Sciences and Soil Protection, Martin Luther Universität Halle-Wittenberg, von-Seckendorff-Platz 3, 06120 Halle (Saale), Germany

2 Technische Universität Berlin, Ernst-Reuter-Platz 1, 10587 Berlin, Germany

3 Soil Physics and Land Management Group, Wageningen University and Research, GAIA Building 101, Droevendaalsesteeg 3, 6708 Wageningen, PB, Netherlands

\section{Introduction}

Cities and their growing population tend to utilize resources from urban surroundings or the countryside to satisfy their needs. High-quality topsoils, for example, are imported from the countryside to be used for urban greening (Cannavo et al. 2018; Deeb et al. 2016b; Rokia et al. 2014) or bog peat is used as main constituent of growing media (Schindler et al. 2016). Thereby, functioning rural ecosystems and landscapes are exploited and disturbed.

Soils are a fundamental ecological resource in a city. They provide several ecosystem functions, such as infiltration, buffering, and cooling (Herrán Fernández et al. 2016). Soil itself is a biological habitat and hence is conducive to biodiversity (Dominati et al. 2010). Being the basis for biomass production, 
soils provide the habitat for plants which in turn provide multiple ecosystem functions, such as cycling of nutrients, water, and energy (Nehls et al. 2014). Especially in cities, plants do not only supply a yield, but greenery helps to alleviate air pollution (Rawski 2019) and to mitigate the urban heat island effect by shading and evaporative cooling (Hoelscher et al. 2016; Price et al. 2015; Santamouris et al. 2018). Additionally, greenery provides recreational space and cools buildings thus having a direct influence on the well-being of urban dwellers (Buchin et al. 2016; Yilmaz et al. 2016).

However, urban soils are often degraded, sealed, and contaminated (Abel et al. 2015; Séré et al. 2008), limiting their ability to fulfill the necessary ecosystem services (Morel et al. 2015). Therefore, the remediation, reconstruction, amelioration, and finally the purpose-designed construction of Technosols (see WRB 2006) is a systemic approach to improve the sustainability of cities (Flores-Ramírez et al. 2018; Rokia et al. 2014). This should not lead to ecosystem degradation elsewhere.

One way to spare the ecosystems of the countryside from the usurpation of the cities and still guarantee the ecosystem services provided by urban soils is to make use of another problem of continuous urbanization - the growing amounts of waste produced in cities (Cannavo et al. 2018; Deeb et al. 2016b). Particular parts of the urban waste can be employed for the construction of Technosols or soil-like substrate. Construction and demolition waste or excavated soil material can serve as mineral component (Rokia et al. 2014). Green waste, compost, and sewage sludge are typical organic components (Deeb et al. 2016b). The variety of components and the means of mixing them in certain ratios can enable the design of soil-like substrates with properties that suit their application (Willaredt and Nehls 2020). Technosols and soillike substrates constructed from urban wastes have been studied regarding their soil physical properties, such as porosity, hydraulic conductivity, and plant-available soil water (PAW) (Deeb et al. 2016a; Jangorzo et al. 2013; Yilmaz et al. 2016), plant growth (Cannavo et al. 2018; Krawczyk et al. 2017), contaminant eluviation (Herrán Fernández et al. 2016; Séré et al. 2008), and further agronomic properties, such as nutrient availability (Rokia et al. 2014; Vidal-Beaudet et al. 2016). According to Herrán Fernández et al. (2016), construction and demolition waste, bio-stabilized material, and green waste can be used as growing media without negative influence on the environment. Soil-like substrates constructed from bricks and green waste have a high porosity, a high proportion of plant-available water (PAW), and high saturated hydraulic conductivities compared with natural soils (Blume and Runge 1978; Nehls et al. 2013; Yilmaz et al. 2016).

The water retention and hydraulic conductivity of soils are determined by the soil texture and soil structure (Amezketa 1999; Vogel et al. 2006) as well as by the share of organic matter (Blume et al. 2016; Smagin et al. 2002). In many soils, the activity of soil organisms, such as earthworms, is one of the main processes for the creation of soil structure (VandenBygaart et al. 2000). Ingestion and digestion of organic and also mineral matter by earthworms leads to the formation of casts which are stable organo-mineral aggregates (Lavelle et al. 1997). These aggregates modify the micro- and mesoporosity of soils (Blouin et al. 2013) and are more stable than other aggregates in soils (Jangorzo et al. 2015). Furthermore, earthworms have an influence on the structure and the porosity of soils by their burrowing activities creating macropores whilst compressing the adjoining soil (Jangorzo et al. 2015; Kooistra and Pulleman 2010). These influences on the physical structure consequently affect the hydraulic properties (Blouin et al. 2013) and the water balance, i.e., infiltration, drainage, and evaporation, of the soil. According to Deeb et al. (2016a), the presence or absence of earthworms better explained the differences in the total moisture ratio of a constructed Technosol than differences in the ratio of the composition of the parent material.

There are three different ecological types of earthworms, according to the classification by Bouché (1977). These three types, anecic, epigeic and endogeic, are not strictly separable and there are many earthworm species that cannot be allocated to one type but rather are intermediate types with characteristics from two or even from all three types (Dunger 1983).

Endogeic and - to a lesser extent - epigeic earthworms enhance the diffuse infiltration of water into the topsoil (Ernst et al. 2009; Shuster et al. 2002; Van Schaik et al. 2016). Anecic earthworms create stable macropores which facilitate preferential flow and hence increase water infiltration and drainage (Larink 2008). Ernst et al. (2009) found a tendency of an endogeic and an anecic earthworm species to enhance the drying of the soil probably due to an enhanced evaporation while an epigeic species enhanced the water storage in the topsoil. Milleret et al. (2009) observed a compacting influence by an endogeic earthworm species leading to a decrease in the PAW. In general, bigger earthworms have the tendency to compact parts of the soil which increases the water retention capacity and leads to more preferential infiltration patterns, while smaller worms tend to be de-compacting. They tend to decrease water retention and homogenize infiltration (Blanchart et al. 1999). Yet, there are interaction processes between these groups that seem to be necessary to maintain and improve a natural soil structure (Blanchart et al. 1999). Jangorzo et al. (2015) found a combination of anecic and endogeic species to be best considering the stability of aggregates. Consequently, the influence on water storage and transfer also varies greatly depending on the earthworm species (Bastardie et al. 2003).

These influences of earthworms on soil properties are intensely studied (e.g., Blanchart et al. 1999; Blouin et al. 2013; Edwards and Lofty 1972), the application of epigeic worms for vermicomposting is widely spread (Domínguez 2018; Edwards 
and Burrows 1988). Earthworm can be regarded as a resource that needs to be properly managed to enhance ecosystem services provided by soils (Lavelle et al. 2006). Yet the deliberate use of earthworms as engineers in the production of Technosols or soil-like substrates, to improve physical soil properties like the water retention capacity, is barely considered.

For instance, it is not clear, if earthworms are able to ingest both compost and technically crushed, sharp brick particles. Therefore, the aim of this study is to examine the capacity of earthworms to change the structure and thus the hydraulic properties of a soil-like substrate constructed from urban wastes. Since such a substrate is not constructed in-situ, it is important to know if earthworm induced soil structures are stable enough to persist, even if the soil material is disturbed and transported to its final destination after the production process.

In a laboratory experiment with ten microcosms (five with and five without earthworms) the following hypotheses are tested:

(i) Earthworms (Dendrobaena veneta) are able to process ground bricks together with organic material to form aggregates.

(ii) The deliberate treatment of a soil-like substrate constructed from urban waste with earthworms changes its water balance compared with a substrate not impacted by earthworms.

(iii) The earthworm activity increases the PAW of the processed material and this change persists even in disturbed samples.

\section{Materials and methods}

\subsection{Substrates, earthworms, and experimental setup}

In order to evaluate the effect of earthworms on the soil hydraulic properties of a substrate from bricks and organic waste, an experimental setup with standardized microcosms with and without earthworms has been chosen. The substrate used in this experiment consists of a mix of ground bricks (GB) sieved to pass $2 \mathrm{~mm}$ and green waste compost (GWC) sieved to pass $5 \mathrm{~mm}$. Both materials were purchased from a local composting company (Galafa GmbH, Falkensee, Germany). Based on the experience by Deeb et al. (2016a), a ratio of $0.7 \mathrm{~cm}^{3} \mathrm{~cm}^{-3} \mathrm{~GB}$ and $0.3 \mathrm{~cm}^{3} \mathrm{~cm}^{-3} \mathrm{GWC}$ was chosen which equals a dry weight ratio of $0.82 \mathrm{~g} \mathrm{~g}^{-1} \mathrm{~GB}$ and $0.18 \mathrm{~g} \mathrm{~g}^{-1}$ GWC (see Table 1 for a characterization of the materials). The rather high fraction of GWC was chosen to ensure sufficient feed for a high number of earthworms over the total experimental period.

In order to guarantee the same soil texture for each of the replicates, the GB were sieved into four fractions: coarse sand $(0.63-2 \mathrm{~mm})$, medium sand $(200-630 \mu \mathrm{m})$, fine sand $(63-200$ $\mu \mathrm{m})$, and silt/clay $(<63 \mu \mathrm{m})$. Then, these fractions were mixed again in the same original mixing ratio for all replicates. The GB and GWC portions were slightly moistened, homogenously mixed with an electrical stirrer (Collomix Xo4 with WK 120), and then filled into microcosm boxes.

Ten PE-boxes each with a rectangular base area of $21.6 \mathrm{~cm}$ $\times 26.4 \mathrm{~cm}$ and one acrylic glass side wall were used as microcosms (Fig. 1). The acrylic glass was installed in order to observe the earthworm activity. Between the observations it was carefully covered with black cardboard as earthworms flee light. The shading permits earthworm activity close to the acrylic glass front even when the light in the laboratory was on. To allow evaporation while keeping the worms inside the boxes, the lids were prepared with mesh-covered holes. The boxes were installed in a slightly tilted position and a fiber glass wick (60 cm hanging water column) was attached in their lower rim to drain any stagnant water. The ends of the plastic-foil coated wicks were inserted in glass bottles to collect drained water.

A total dry weight of $9.67 \mathrm{~kg}$ of the mixture was finally filled into the boxes and compacted to achieve a height of $19 \mathrm{~cm}$ (i.e., a bulk density of $0.90 \mathrm{~g} \mathrm{~cm}^{-3}$ ). The experiment was set up in a cooling chamber at $20^{\circ} \mathrm{C}$ for 140 days.

Five boxes (W1-5) were equipped with earthworms, the other five boxes (C1-5) served as control. The earthworms placed in the microcosms were chosen based on the following criteria: (i) they should be active under the given laboratory conditions, (ii) they need to burrow in the topsoil layer, and (iii) they must be available. Dendrobaena veneta was hence chosen as an epi-endogeic species, which usually lives and
Table 1 Properties of mineral and organic materials used for the substrate

\begin{tabular}{lllll}
\hline Material & Origin & Particle size distribution & Solid density $\left(\mathrm{g} \mathrm{cm}^{-3}\right)$ & $\mathrm{C}_{\text {tot }}\left(\mathrm{g} \mathrm{g}^{-1}\right)$ \\
\hline Brick sand & $\begin{array}{c}\text { Urban building } \\
\text { and demolition waste }\end{array}$ & $\begin{array}{l}\text { Coarse sand: } 31.1 \mathrm{wt} \% \\
\text { Medium sand: } 44.1 \mathrm{wt} \%\end{array}$ & 2.63 & 0.024 \\
& & Fine sand: $19.3 \mathrm{wt} \%$ & & \\
& & Silt and clay: $2.5 \mathrm{wt} \%$ & & \\
Compost & Urban cuttings & - & 2.06 & 0.268 \\
T0-material & Brick sand and compost & - & 2.50 & 0.061 \\
\hline
\end{tabular}




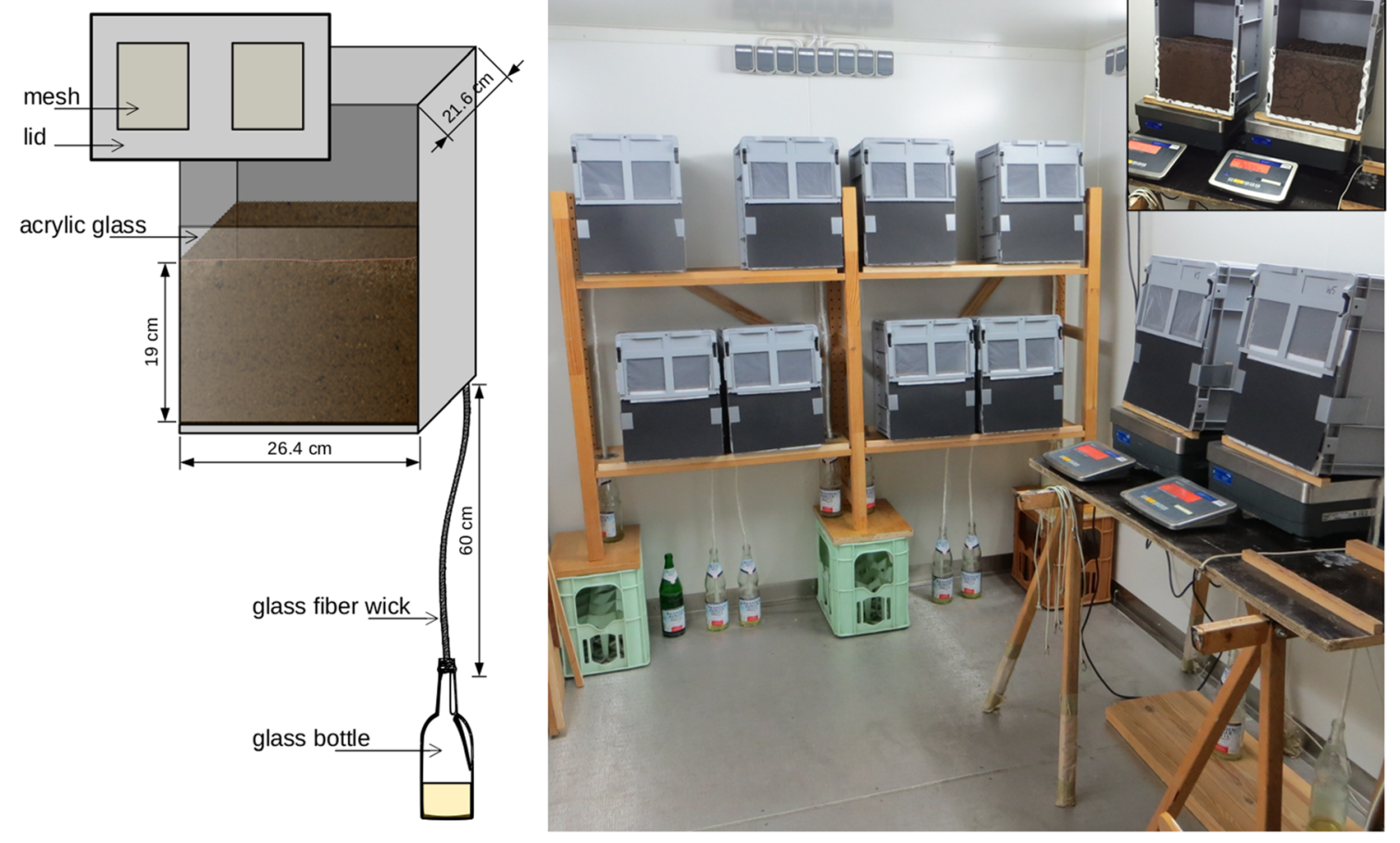

Fig. 1 Experimental set up and schematic representation of the microcosms used

feeds in the litter layer (epigeic part), but also burrows vertically and horizontally up to 0.3 to $0.5 \mathrm{~m}$ deep in the topsoil while it consumes organic matter that is incorporated into the soil (endogeic part) (Dunger 1983; Felten and Emmerling 2009). D. veneta prefers temperatures of $15-25^{\circ} \mathrm{C}$ and tolerates a wide moisture range (Domínguez and Edwards 2011; Edwards and Bohlen 1996). As D. veneta is commonly used as bait worm, the earthworms were bought from a fishing supply shop.

Before introducing the earthworms into the microcosms, they were washed with tap water and kept in wet paper towels for about $24 \mathrm{~h}$ for intestinal voiding. Then they were washed again, dried cautiously with paper towels, weighed, and divided into five portions of 50 individuals of approximately the same weight (Table 2).

Table 2 Number and weight of earthworms at the beginning and at the end of the experiment per box

\begin{tabular}{llllll}
\hline \multirow{2}{*}{ Box } & \multicolumn{2}{l}{ Initial earthworms } & & \multicolumn{2}{l}{ Earthworms at the end } \\
\cline { 2 - 3 } & Number & Weight $(\mathrm{g})$ & & Number & Weight (g) \\
\hline W1 & 50 & 41.03 & & 5 & 1.4 \\
W2 & 50 & 41.95 & & 8 & 2.3 \\
W3 & 50 & 41.23 & & 12 & 3.3 \\
W4 & 50 & 42.01 & & 10 & 2.0 \\
W5 & 50 & 41.99 & & 5 & 1.2 \\
C2 & - & - & 4 & 0.9 \\
\hline
\end{tabular}

Earthworms live in aerobic and moist conditions. Thus, the containers were initially irrigated to a water content of 0.29 $\mathrm{cm}^{3} \mathrm{~cm}^{-3}$, slightly more than the water content at field capacity (FC, pF 1.8). The boxes were regularly weighed and subsequently irrigated to this water content to compensate for evaporation and drainage losses: twice a week until day 52, then once a week until day 108. Finally, starting on day 115 the boxes were left to dry out for five weeks and were still monitored weekly to observe how the earthworm activity influenced the water balance in drier circumstances.

Despite the effort to make closed boxes with meshes on the openings, during the first 14 days a total of 30 earthworms managed to escape through and were found outside the boxes. Unfortunately, it could not be traced from which boxes the individuals escaped. From day 14 on no further earthworms were found outside the boxes as then the cooling chamber was continuously illuminated. The illumination led to a higher heat load which increased the number of cooling cycles thereby decreasing the relative air humidity. One earthworm was seen in control box C2. Between days 108 and 111, the climatic chamber was accidentally switched off leading to a rise in air temperature to $30^{\circ} \mathrm{C}$ on the third day.

\subsection{Monitoring the water balance and earthworm activity during the experiment}

Before each irrigation, all the boxes and the drained water were always weighed (with Sartorius Signum ${ }^{\circledR} 1$ balance). The box weights were further monitored weekly after the irrigation was 
stopped. Each time the boxes were weight, images of the front of the microcosms were taken in order to observe the effects of the earthworms, e.g., aggregation and structuring processes. This was done using a flatbed scanner (EPSON perfection 2480 ) with a resolution of 1200 dpi which was mounted on the acrylic glass side of the microcosm boxes.

\subsection{Sample preparation after the experiment}

After the end of the experiment, the boxes were emptied onto a plastic sheet; the earthworms were collected by handsorting, counted, and weighed after intestinal voiding (see Table 2). In this study the experimental set up in boxes is considered a production step. The further use of the obtained soil-like substrates as planting substrates requires dislocation. As we are interested in whether the impact of earthworms remains relevant when soil-like substrates are used as a plant habitat, disturbed material was used for further investigation. The substrate was mixed, homogenized, and partitioned according to the standardized procedure dividing by quartering (LABO 2002). This procedure was repeated until about $400 \mathrm{~g}$ of the substrate were left as samples for the measurement of water retention curves, determination of Ctot (using LOI in the muffle furnace according to the German norm DIN 19684-3 (2005)), and for light microscopy. The samples for light microscopy were sieved to pass $1 \mathrm{~mm}$. Of both fractions $(<1$ $\mathrm{mm},>1 \mathrm{~mm}$ ) micrographs were taken through a light microscope for two different magnifications (Nikon, SMZ-U).

\subsection{Measurement of the water retention curve}

The water retention curves of (i) the original substrate (T0) and disturbed samples of (ii) the $\mathrm{C}$ substrates and (iii) the $\mathrm{W}$ substrates at the end of the experiment were determined using the simplified evaporation method (HYPROP ${ }^{\circledR}$ device, METER group AG) (Peters and Durner 2015; Schindler 1980). Therefore, one sample of the disturbed processed substrate of each box and five replicates with original substrate were packed into $250 \mathrm{~cm}^{3}$ steel cylinders at a bulk density of $1.15 \mathrm{~g} \mathrm{~cm}^{3}$. This 1.3 -times higher density than the bulk density in the experimental boxes was necessary to be able to handle the samples after their full saturation.

In order to calculate the PAW, the volumetric water content at $\mathrm{pF} 4.2$ was determined using a pressure plate extractor (Soilmoisture Equipment Corp., Santa Barbara, USA). Here, too, one sample of the disturbed processed substrate of each box and five replicates of the original substrate were analyzed.

\subsection{Data processing and analyses}

The images taken from the front of the boxes and the micrographs of the substrates have been analyzed qualitatively comparing results of earthworm activity (fraction of substrate affected by earthworm activity) and aggregate formation between the $\mathrm{W}$ and the $\mathrm{C}$ treatments and in between the $\mathrm{W}$ treatments.

To analyze the influence of the earthworms on the soil moisture, the different components of the water balance were measured or calculated right before each irrigation: the gravimetric water content $\left.\mathrm{g}_{\mathrm{g} \mathrm{g}}{ }^{-1}\right)$, the volume of seepage water $\mathrm{S}(\mathrm{mm}$ $\left.\mathrm{d}^{-1}\right)$, and the daily evaporation $\mathrm{E}\left(\mathrm{mm} \mathrm{d}^{-1}\right)$. The water content in the boxes is stated as gravimetric water content as the volume of the substrate in the microcosms was subject to change.

The data of the water retention curve measurements with HYPROP was revised for inconsistencies. The PAW was calculated from the water contents of the samples at $\mathrm{pF} 1.8$ and $\mathrm{pF} 4.2$.

In order to test the treatments for significant differences, the data of the water balance and of the measurements of the water retention for $\mathrm{W}, \mathrm{C}$, and $\mathrm{T} 0$ was tested for normality of distribution with the Shapiro-Wilk tests (R, version 3.3.1). If normality was verified, Student's $t$ test was used to test for significant differences in the means of the variables for the treatments. Linear regression models were calculated to test for significant correlations between the variables of the water balance and time. Correlations and differences in mean were considered significant at $p<0.05(*), i<0.01(* *)$, and $p<$ $0.001(* * *)$.

\section{Results}

\subsection{Impacts of earthworm activity}

Regarding the images taken of the W-boxes, an increase in the fraction of substrate impacted by the activity of the earthworms was observed over time (Fig. 2). The earthworms immediately started to burrow. There is a peak in the area of the burrow system at the end of the second irrigation regime (day 108). The reduction of the irrigation frequency to once a week (after day 52) did not influence the earthworms' activity while after stopping irrigation (after day 108) new burrows were not detected. While some of the burrows seem to be stable over time, others - especially in the upper horizon - were refilled during subsequent earthworm activities. The boxes with earthworms show a similar alteration of the visible surfaces of the substrate over time. Only in box W3 the burrowing activity visible on the front wall is distinctly higher. The changes in the irrigation scheme (after day 52 and day 108) are also visible in the changing color of the substrate of the C-boxes (Fig. 2).

The activity of the earthworms could also be observed on the surface of the substrate. The surface of $\mathrm{C}$ stayed flat throughout the experiment. Only the color changed, turning lighter, especially in the last phase of the experiment. The surfaces in the W-boxes changed visibly since the first day of the experiment. The burrowing activity as well as the casts of the earthworms created a rough, uneven surface. The 


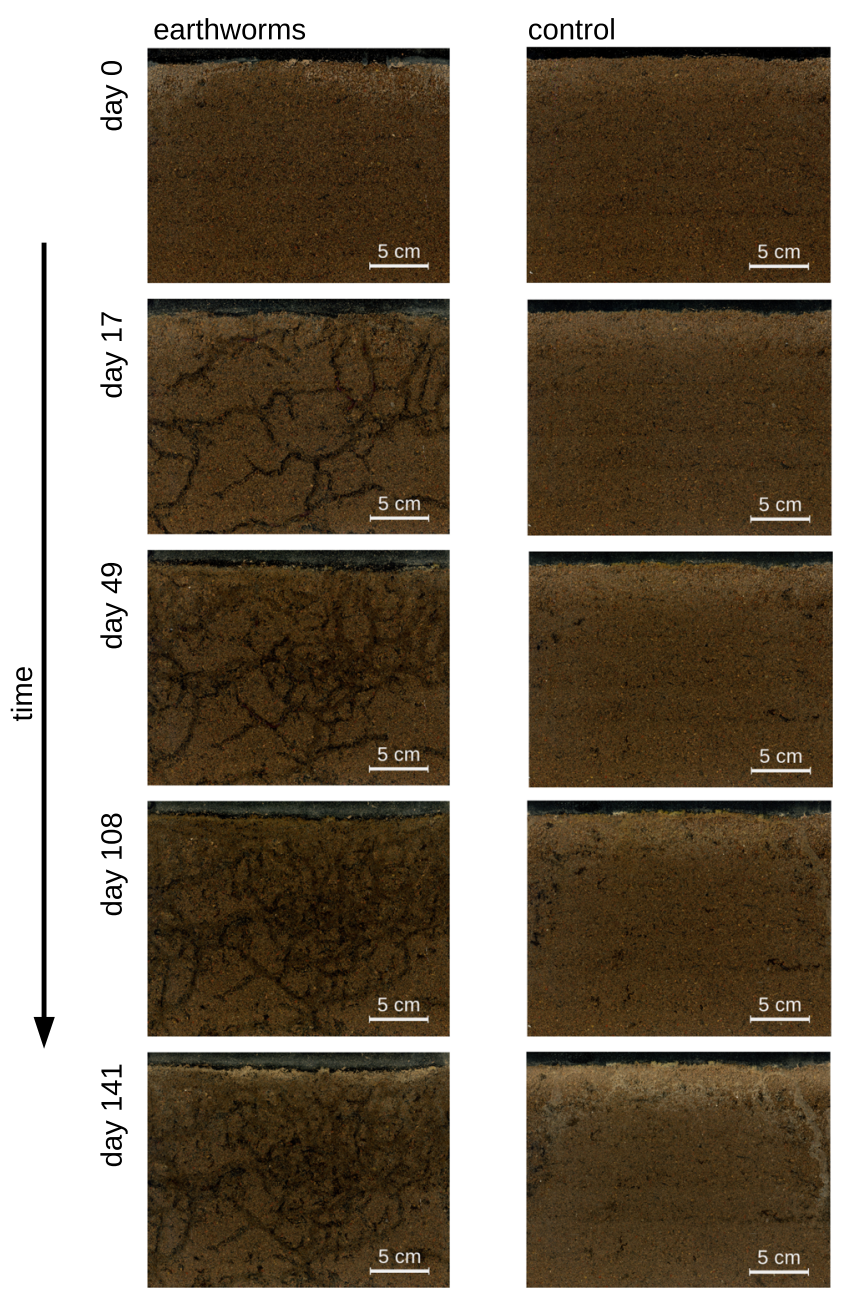

Fig. 2 Scans of the front of the microcosms showing the development of pore structures in a brick-compost mixture processed by earthworms (W3) and in a control box (C3)

deposition of casts on the surface became less after the cooling chamber was permanently illuminated. The color of the Wsubstrate only changed slightly. The volume of the substrate decreased in all ten microcosms - primarily in the phase without irrigation - but not measurably, leading to gaps between the substrate and the inner walls of the boxes.

A change of the structure of the substrate due to the earthworms' activity was also observed at the microscopic scale (Fig. 3). This change is especially visible in the micrographs of the particle size fraction $>1 \mathrm{~mm}$ where aggregates that combine organic and mineral components were detected only in the $\mathrm{W}$-substrate.

A slight decomposition of carbon was observed for both treatments. However, the differences in $\mathrm{C}_{\mathrm{tot}}$ are not significant $(n=5, p>0.05)$, neither between T0 $\left(5.42 \pm 0.36 \mathrm{~g} \mathrm{~g}^{-1}\right)$ and the processed substrates nor between $\mathrm{C}-\left(5.08 \pm 0.37 \mathrm{~g} \mathrm{~g}^{-1}\right)$ and the W-substrate $\left(5.10 \pm 0.19 \mathrm{~g} \mathrm{~g}^{-1}\right)$.

At the end of the experiment, the number of earthworms collected from the boxes is clearly lower than their initially introduced number (Table 2). Some of the collected earthworms were identified as juvenile.

\subsection{Water balance of the microcosms during the experiment}

During the time span of 20 weeks, the gravimetric water content ${ }_{\mathrm{g}}$, the daily evaporation $\mathrm{E}$, and the daily seepage water $\mathrm{S}$ were monitored (Fig. 4). As the results are based on a number of five samples per treatment, all statistical results are to be handled with care. After an initial phase of two weeks, the 18 weeks starting on day 17 were analyzed.

During the first phase (irrigation twice a week) seepage hardly changes with time, there is only a small decrease measurable in C-boxes (Fig. 4, bottom panel, $R^{2}=0.06, p<0.05$ ). After day 17, coinciding with the continuous illumination of the cooling chamber, there was a pronounced increase in evaporation (Fig. 4, middle panel). Then the evaporation just like the water content stays rather stable during the first phase (Fig. 4, top panel).

The longer timespan between measurements in the second phase (irrigation once a week) leads to a decrease of seepage by a factor of about 1.7 compared with the higher irrigation frequency. During this phase seepage is stable. The magnitude of evaporation is not influenced by the frequency of irrigations and stays more or less the same from day 49 to the end of the second phase of the experiment. For the C-treatment, evaporation is about twice as high as seepage; for, W this difference is either slightly less or-for box W3non-existent. The water content is lower at the time of the measurement in the second phase compared with the first phase.

In the third phase, as the soil dries out, water content and evaporation decrease steadily while seepage drops to zero a week after the irrigation is stopped.

Differences concerning the three variables $\mathrm{g}, \mathrm{E}$, and $\mathrm{S}$ between $\mathrm{W}$ - and C-boxes are hardly evident throughout the first weeks of the experiment. The mean and median evaporation for $\mathrm{W}$ are higher than for $\mathrm{C}$ between day 21 and day 38 and the water content is lower. On day 42 this relationship inverses abruptly, and evaporation for $\mathrm{C}$ is higher than for $\mathrm{W}$ and the water content for $\mathrm{C}$ is slightly lower than for W. Evaporation remains higher for $C$ until the last day (141) of the experiment, when $\mathrm{W}$ and $\mathrm{C}$ reach the same value. On this last day of the experiment, evaporation is especially reduced for the boxes $\mathrm{C} 1$ and $\mathrm{C} 3$, the ones with the lowest water content of less than $13 \mathrm{~g} \mathrm{~g}^{-1}$.

The box W3 differs from the other boxes. It has the highest seepage and the lowest evaporation of all the ten microcosms from day 42 on. During the third phase of the experiment, when the irrigation is stopped and seepage drops to zero, W3 is the box with the highest water content. 
Fig. 3 Micrographs of a brickcompost mixture processed by earthworms (W3) and in from a control box (C2)

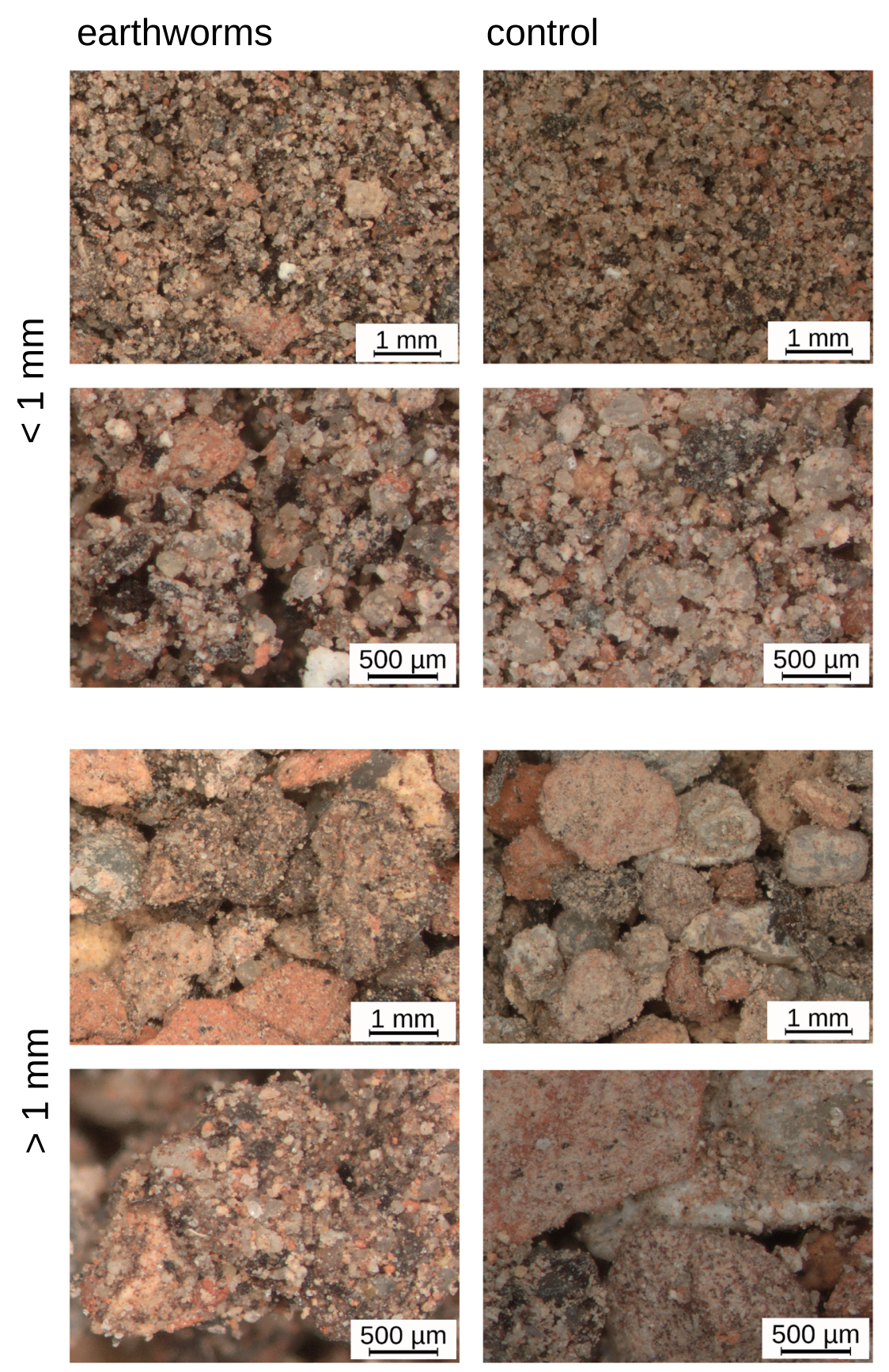

\subsection{Water retention of the processed substrate}

The differences observed for the water balance in the microcosms between $\mathrm{W}$ and $\mathrm{C}$ during the experiment persists when disturbed samples of the processed substrate are analyzed for water retention (Fig. 5) using the HYPROP-device. There is a high variance of the volumetric water content ${ }_{v}$ in the replicates at low $\mathrm{pF}$-values. The variance of the water content for the original substrate (T0) is high for the whole range of $\mathrm{pF}$-values, whereas for $\mathrm{C}$ it gets close to zero for $\mathrm{pF}$-values $>1.6$.
At $\mathrm{pF} 1.8$ the water content is about the same for $\mathrm{T} 0$ and $\mathrm{C}$, while it is higher for $\mathrm{W}$. The difference between $\mathrm{C}$ and $\mathrm{W}$ of almost $0.02 \mathrm{~cm}^{3} \mathrm{~cm}^{-3}$ is highly significant $(n=5, p<0.01)$. Such a difference can be observed for the whole $\mathrm{pF}$-range covered by the HYPROP-measurements ( $\mathrm{pF} 1.5-2.8$ ). At higher $\mathrm{pF}$-values of this range, differences between $\mathrm{W}$ and T0 become significant $(n=5, p<0.05)$. At $\mathrm{pF} 4.2$ the water content was determined with the pressure plate extractor and shows almost the same values for all three treatments.

In sum, the mean volume of plant-available water of the Wsubstrate is 0.015 and $0.02 \mathrm{~cm}^{3} \mathrm{~cm}^{-3}$ higher than of T0 and $\mathrm{C}$ 

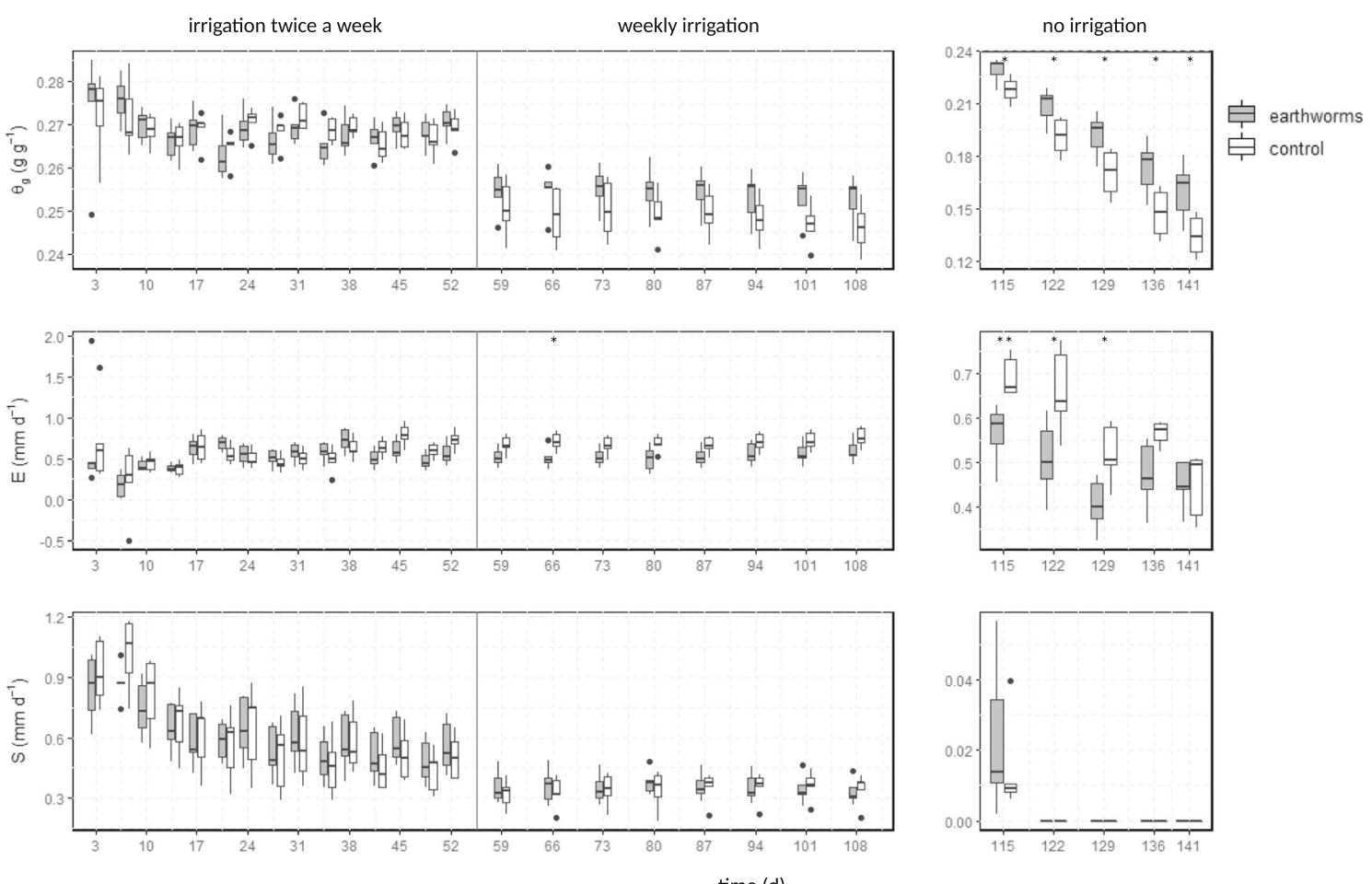

Fig. 4 Development of the moisture content ( $\mathrm{g}$ ), the evaporation (E), and the seepage water (S) during the experiment in the control and the worm boxes. Boxplots should be interpreted with care since they are the result

(Fig. 6). Here again, the difference between the $\mathrm{W}$ - and the $\mathrm{C}$ substrate is highly significant $(n=5, p<0.01)$. The variance of the PAW of T0 is again higher than for the processed substrates.

\section{Discussion}

The earthworm $D$. veneta is able to process urban wastes like ground bricks. The micrographs from the aggregates show, that the earthworms do not only incorporate the organic material of the compost but also bricks. As the fraction impacted by earthworm activity increases during the phases with irrigation and as young earthworms occurred, the composition of the substrate seems to provide an acceptable habitat for the earthworms as long as tolerable humidity and temperature are kept. It cannot be stated for sure when in the experimental period the number of earthworms in the boxes was reduced. The escape of some earthworms from the boxes during the first 2 weeks of the experiment is not necessarily due to the quality of the substrate. Earthworms are very active in the dark and especially epigeic worms are known to disappear from experimental units (Chatelain and Mathieu 2017; Fründ et al. 2010; Wurst et al. 2008). With the illumination of the cooling chamber, the escaping could hence be stopped. However, the continuous illumination had further side effects. Since the relative air humidity was decreased due to the higher heat load and the necessary higher number of cooling cycles, the evaporation from the boxes was increased. In of only five measurements each. Differences in mean were considered significant at $p<0.05(*)$ and $p<0.01(* *)$

accordance a decreasing seepage during the first phase of the experiment is observable for both $\mathrm{W}$ - and C-boxes.

From this time onwards, the earthworms stayed within the substrate and were less active on its surface. This could have influenced the impact of the earthworms on the evaporation since the transport of wetter material from deeper layers to the surface was reduced and there were less macropores enlarging the evaporative surface. Therefore, we discuss all the results starting from day 17.

We observed a compaction of the substrate in the microcosms. According to Jangorzo et al. (2013), Technosols compact due to gravity and rainfall/irrigation. Such a compaction leads to a reduction of macro- and mesopores in the relatively loosely packed substrate. A slight decrease of the filling height of the substrate in the boxes due to compaction - particularly in the last phase of the experiment - can in fact be noticed on the scans from the front of the microcosms. This change is yet quite small and due to high variability in the substrate-surface in the W-boxes the accuracy of possible measurements of this compaction is too low to quantify it.

There are statistically significant alterations regarding the water balance during the experiment especially in the phase without further irrigation (after day 115). Until day 108, differences in the water content and evaporation between $\mathrm{W}$ - and C-boxes are not statistically significant. However, starting from day 42 the influence of the earthworm activity on the water content becomes more obvious. Consequently, there is a trend of a lower evaporation from the $\mathrm{W}$-substrate compared with the $\mathrm{C}$-boxes. 

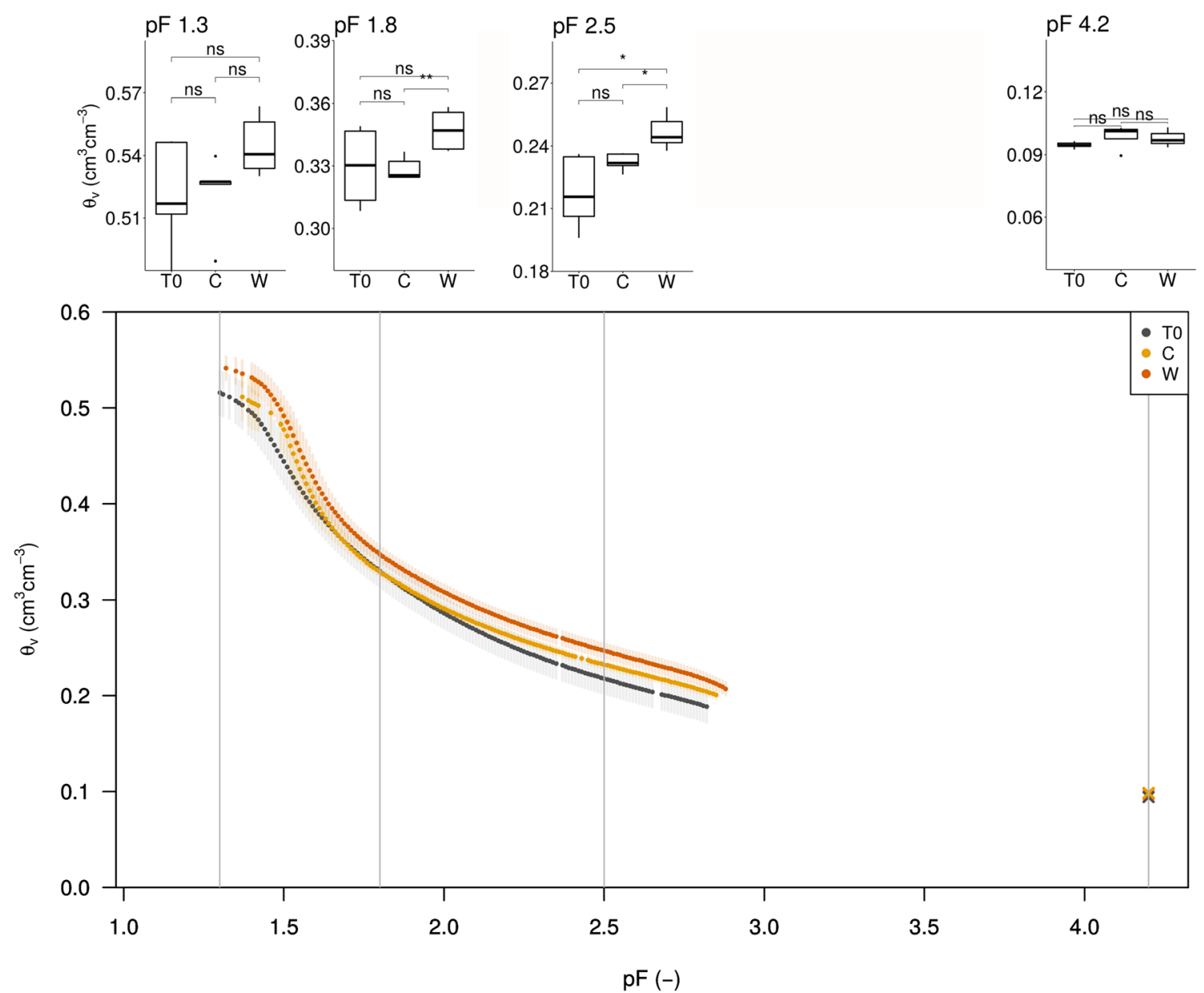

Fig. 5 Water retention curves, i.e., volumetric water content ( $\left.{ }_{v}\right)$ against the $\mathrm{pF}$, of packed cylinders with initial substrate (T0) as well as disturbed samples of the processed substrate from the control boxes (C) and the boxes with earthworms (W). The data for $\mathrm{pF}<3$ were obtained using the simplified evaporation method, for $\mathrm{pF}=4.2$ using a pressure plate extractor. The bold lines are the mean of each group. The shaded sections depict

the standard deviation. The boxplots show the water retention capacities at the four displayed $\mathrm{pF}$-values in more detail. They should be interpreted with care since they are the result of only five measurements each. Differences in mean were considered significant at $p<0.05(*)$ and $p<$ $0.01(* *)$

According to analyses by Smagin and Prusak (2008) earthworm casts have a higher water retention capacity than the surrounding soil throughout the WRC. This could be due to finer pores in the casts and a stronger adsorption of water due to the formation of organo-mineral aggregates.

The reduced evaporation from the $\mathrm{W}$-substrate could be caused by the burrows of the earthworms leading to a loss in connectivity of fine pores from the lower layers of the substrate to the surface (Kutílek and Nielsen 1994). Additionally, these burrows enhance the infiltration of irrigation water to deeper substrate layers (see below). On the other hand, these macropores may lead to a higher evaporation from wet soils as they increase the evaporative soil surface. However, the gas exchange between the substrate and atmosphere was limited in the cooling chamber.

Even though the differences between the $\mathrm{W}$ - and the $\mathrm{C}$ boxes showed a systematical trend starting from day 42 , the low number of replicates and the high variability between the boxes restricted statistical significance at the chosen $95 \%$ - level. Additionally, during the phases with irrigation, the substrates were almost saturated with water and evaporation rates were mainly driven by atmospheric conditions and not limited by soil suction. Thus, the influence of the activity of earthworms could not become effective. Consequently, these differences become significant during the drying phase.

In the box with the highest earthworm activity-W3 - the contradicting influences of the earthworm activity on the water balance of the substrate are most pronounced: the seepage was the highest and the evaporation the lowest compared with all the other boxes. On the one hand, earthworms increase the macroporosity due to their burrowing activity and thus enhance the seepage, e.g., due to preferential flow. On the other hand, they form aggregates that retain the water more strongly and result in lower evaporation rates. In sum, the water content does not differ from that of the control boxes.

By taking disturbed samples of the substrate and relocating it, the structure of the burrowing activity of the earthworm, 


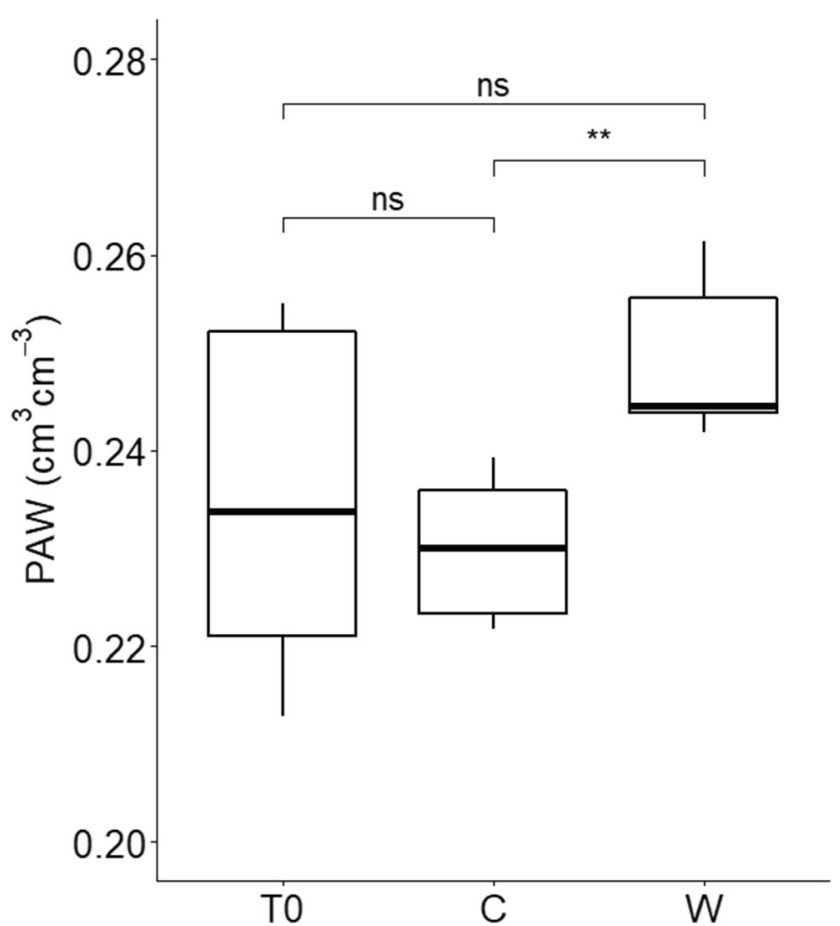

Fig. 6 Plant-available soil water (PAW) for the initial substrate (T0) and the processed substrate of the control boxes $(\mathrm{C})$ and the boxes with earthworms (W). Boxplots should be interpreted with care since they are the result of only five measurements each. Differences in mean were considered significant at $p<0.01(* *)$

i.e., the macropores, is destroyed. Yet, the aggregates formed by the ingestion of the earthworms persist (see Fig. 3). Since differences in water retention characteristics between the substrate processed by earthworms and the control are also observable in the disturbed samples, we assume that the increase in retained water in these disturbed samples is caused by the produced aggregates. In order to verify if the enhanced water retention capacity of the substrate of the W-boxes persists after transport and with time, the stability of the aggregates formed by earthworms could be measured. Deeb et al. (2017) reported that Aporrectodea caliginosa was responsible for the aggregate stability of processed Technosols consisting of excavated sub soil material and green waste compost.

In this study, we thoroughly sorted the earthworms by hand from the substrate. In practical applications, it is likely that at least some earthworms and cocoons will be transported with the processed material. They could further process the substrate on site and continue to influence the soil structure. Such earthworm introduction could imply the risk of establishment of non-native species and interference with existing species (Craven et al. 2017).

Before such a substrate can be applied for urban greening, some additional points should be considered. The organic matter content of the substrate used in this experiment is quite low compared with usually purchasable growing substrate. However, compared with natural soils the $\mathrm{C}_{\text {tot }}$-concentration is rather high. Therefore, the risk of enhanced leaching of nutrients should be studied.

In this study, we used only one mixing ratio of only two components with one earthworm species. It is well known that the original material as well as the earthworm species might have a large influence on the aggregate formation and stability (Schrader and Zhang 1997). Other mixing ratios, e.g., with less organic material, other input materials, and other earthworm species could lead to different results. Generally, such a soil-like substrate will be subjected to a certain evolution once it is implemented as a planting substrate. Therefore, approaches aiming for designing soil-like substrates with purpose specific properties should be aware of this early pedogenesis. It should be taken into account that properties may improve but may also worsen.

\section{Conclusions}

In this study, the capacity of earthworm $D$. veneta to change the hydraulic properties of a soil-like substrate made from urban waste was tested in a microcosm experiment for 4 months. With the images taken from the front of the microcosms, it could be observed that the earthworms are able to process the mixture of crushed bricks and compost. As long as the moisture conditions were adequate, the earthworms were active, burrowed the substrate, and formed aggregates.

The evaporation in the microcosms with earthworms was reduced compared with the controls. This is most likely due to a higher water retention capacity of the earthworm cast. For the volume of seepage water, an effect of the earthworms could only be observed for the box with the highest earthworm activity. Here, there was strong burrowing activity and increased seepage compared with the other boxes, most likely due to preferential flow through the macropores.

The measurements of the water retention curves of the disturbed and translocated substrate reveal a persistence of the earthworms' influence on the water content observed during the experiment. At field capacity, the water content in the substrates processed by earthworms is higher than for the control and the initial substrate. Differences in the water content at the permanent wilting point are not as distinct. This results in a proportion of PAW that is on average $8.6 \%$ higher for the substrate treated with earthworms than for the control. While the macropores are disturbed when relocating the substrate and thus preferential flow is no longer a relevant factor, the structure of the cast with its higher water retention capacity persists.

Authors' contributions All authors contributed to the study conception and design. Material preparation, data collection, and analysis were performed by Susanne Ulrich, Moreen Willaredt, Thomas Nehls, and Loes van Schaik. The first draft of the manuscript was written by Susanne Ulrich and all authors commented on previous versions of the manuscript. All authors read and approved the final manuscript. 
Funding Open Access funding provided by Projekt DEAL. The authors are grateful for the support of the Technische Universität Berlin. MW acknowledges Berlin International Graduate School in Model and Simulation Based Research (BIMoS) for support with a PhD-fellowship. LvS acknowledges support by the DFG (scha1719/1-2). TN acknowledges support by the project Vertical Green 2.0 (BMBF grant no. 01LF1803A). Additionally, the ZELMI of the TUB, especially Irene Preuß, is gratefully acknowledged for the support and production of the micrographs.

Open Access This article is licensed under a Creative Commons Attribution 4.0 International License, which permits use, sharing, adaptation, distribution and reproduction in any medium or format, as long as you give appropriate credit to the original author(s) and the source, provide a link to the Creative Commons licence, and indicate if changes were made. The images or other third party material in this article are included in the article's Creative Commons licence, unless indicated otherwise in a credit line to the material. If material is not included in the article's Creative Commons licence and your intended use is not permitted by statutory regulation or exceeds the permitted use, you will need to obtain permission directly from the copyright holder. To view a copy of this licence, visit http://creativecommons.org/licenses/by/4.0/.

\section{References}

Abel S, Nehls T, Mekiffer B, Wessolek G (2015) Heavy metals and benzo[a]pyrene in rubble soils. J Soils Sediments 15(8):17711780. https://doi.org/10.1007/s11368-014-0959-4

Amezketa E (1999) Soil aggregate stability: A review. J Sustain Agr 14: 83-151. https://doi.org/10.1300/J064v14n02_08

Bastardie F, Capowiez Y, de Dreuzy J-R, Cluzeau D (2003) X-ray tomographic and hydraulic characterization of burrowing by three earthworm species in repacked soil cores. Appl Soil Ecol 24:3-16. https://doi.org/10.1016/S0929-1393(03)00071-4

Blanchart E, Albrecht A, Alegre J, Duboisset A, Gilot C, Pashanasi B, Lavelle P, Brussaard L (1999) Effects of earthworms on soil structure and physical properties. In: Lavelle P, Brussaard L, Hendrix P (eds) Earthworm management in tropical agrosystems. CABI publishing, UK

Blouin M, Hodson ME, Delgado EA, Baker G, Brussaard L, Butt KR, Dai J, Dendooven L, Peres G, Tondoh JE, Cluzeau D, Brun J-J (2013) A review of earthworm impact on soil function and ecosystem services. Eur J Soil Sci 64(2):161-182. https://doi.org/10.1111/ ejss. 12025

Blume H-P, Runge M (1978) Genese und Ökologie innerstädtischer Böden aus Bauschutt. Z Pflanz Bodenkunde 141:727-740

Blume H-P, Brümmer GW, Horn R, Kandeler E, Kögel-Knabner I, Kretzschmar R, Stahr K, Wilke B-M (2016) Scheffer/ Schachtschabel: Lehrbuch der Bodenkunde. Spektrum Akademischer Verlag, Heidelberg

Bouché MB (1977) Strategies lombriciennes. In: Lohm U, Person T (eds) Organisms as components of ecosystems. Ecological Bulletin, Stockholm

Buchin O, Hoelscher M-T, Meier F, Nehls T, Ziegler F (2016) Evaluation of the health-risk reduction potential of countermeasures to urban heat island. Energ Buildings 114:27-37. https://doi.org/10.1016/j. enbuild.2015.06.038

Cannavo P, Guénon R, Galopin G, Vidal-Beaudet L (2018) Technosols made with various urban wastes showed contrasted performance for tree development during a 3-year experiment. Environ Earth Sci 77: 650. https://doi.org/10.1007/s12665-018-7848-x

Chatelain M, Mathieu J (2017) How good are epigeic earthworms at dispersing? An investigation to compare epigeic to endogeic and anecic groups. Soil Biol Biochem 111:115-123. https://doi.org/10. 1016/j.soilbio.2017.04.004

Craven D, Thakur MP, Cameron EK, Frelich LE, Beausejour R, Blair RB, Blossey B, Burtis J, Choi A, Davalos A, Fahey TJ, Fisichelli NA, Gibson K, Handa IT, Hopfensperger K, Loss SR, Nuzzo V, Maerz JC, Sackett T, Scharenbroch BC, Smith SM, Vellend M, Umek LG, Eisenhauer N (2017) The unseen invaders: introduced earthworms as drivers of change in plant communities in North American forests (a meta-analysis). Glob Change Biol 23(3): 1065-1074. https://doi.org/10.1111/gcb.13446

Deeb M, Grimaldi M, Lerch TZ, Pando A, Gigon A, Blouin M (2016a) Interactions between organisms and parent material of a constructed Technosol shape its hydrostructural properties. SOIL 2:163-174. https://doi.org/10.5194/soil-2-163-2016

Deeb M, Grimaldi M, Lerch TZ, Pando A, Podwojewski P, Blouin M (2016b) Influence of organic matter on hydro-structural properties of constructed technosols. Pedosphere 26(4):486-498. https://doi. org/10.1016/S1002-0160(15)60059-5

Deeb M, Desjardins T, Podwojewski P, Pando A, Blouin M, Lerch TZ (2017) Interactive effects of compost, plants and earthworms on the aggregations of constructed Technosols. Geoderma 305:305-313. https://doi.org/10.1016/j.geoderma.2017.06.014

DIN 19684-3 2005 Chemische Laboruntersuchungen, Teil 3: Bestimmung des Glühverlusts und des Glührückstands (DIN19684-3:2005) Beuth-Verlag, Berlin, 2005

Dominati E, Patterson M, Mackay A (2010) A framework for classifying and quantifying the natural capital and ecosystem services of soils. Ecol Econ 69(9):1858-1868. https://doi.org/10.1016/j.ecolecon. 2010.05 .002

Domínguez J (2018) Earthworms and Vermicompost. In: Ray S (ed) Earthworms-The ecological engineers of soil. IntechOpen, London

Domínguez J, Edwards CA (2011) Biology and ecology of earthworm species used for vermicomposting. In: Arancon NQ, Edwards CA, Sherman RI (eds) Vermiculture technology: earthworms, organic wastes, and environmental management. CRC Press, USA

Dunger W (1983) Tiere im Boden. A. Ziemsen Verlag, Wittenberg Lutherstadt

Edwards CA, Bohlen PJ (1996) Biology and ecology of earthworms. Chapman \& Hall, London

Edwards CA, Burrows I (1988) The potential of earthworm compost as plant growth media. In: Edwards CA, Neuhauser EF (eds) Earthworms in waste and environmental management. SPB Academic Publishing bv, The Hague

Edwards CA, Lofty JR (1972) Biology of earthworms. Chapman \& Hall, London

Ernst G, Felten D, Vohland M, Emmerling C (2009) Impact of ecologically different earthworm species on soil water characteristics. Eur J Soil Biol 45:207-213. https://doi.org/10.1016/j.ejsobi.2009.01.001

Felten D, Emmerling C (2009) Earthworm burrowing behaviour in 2D terraria with single- and multi-species assemblages. Biol Fert Soils 45:789-797. https://doi.org/10.1007/s00374-009-0393-8

Flores-Ramírez E, Abel S, Nehls T (2018) Water retention characteristics of coarse porous materials to construct purpose-designed plant growing media. Soil Science and Plant Nutrition 64(2):181-189. https://doi.org/10.1080/00380768.2018.1447293

Fründ H-C, Butt K, Capowiez Y, Eisenhauer N, Emmerling C, Ernst G, Potthoff M, Schädler M, Schrader S (2010) Using earthworms as model organisms in the laboratory: recommendations for experimental implementations. Pedobiologia 53:119-125. https://doi.org/ 10.1016/j.pedobi.2009.07.002

Herrán Fernández A, Lacalle RG, Iturritxa Vélez del Burgo MJ, Martínez Azkenuenaga M, Vilela Lozano J (2016) First results of Technosols constructed from municipal waste in Victoria-Gasteiz (Spain). Span J Soil Sci 6(1):64-81. https://doi.org/10.3232/SJSS.2016.V6.N1.06

Hoelscher M-T, Nehls T, Jänicke B, Wessolek G (2016) Quantifying cooling effects of façade greening: shading, transpiration and 
insulation. Energ Buildings 114:283-290. https://doi.org/10.1016/j. enbuild.2015.06.047

Jangorzo NS, Watteau F, Schwartz C (2013) Evolution of the pore structure of constructed Technosols during early pedogenesis quantified by image analysis. Geoderma 207-208:80-192. https://doi.org/10. 1016/j.geoderma.2013.05.016

Jangorzo NS, Watteau F, Hajos D, Schwartz C (2015) Nondestructive monitoring of the effect of biological activity on the pedogenesis of a Technosol. J Soils Sediments 15:1705-1715. https://doi.org/10. 1007/s11368-014-1008-z

Kooistra MJ, Pulleman MM (2010) Features related to faunal activity. In: Stoops G, Marcelino V, Mees F (eds) Interpretation of micromorphological features of soils and regoliths, chapter 16. Elsevier Science

Krawczyk A, Domagala-Świątkiewicz I, Lis-Krzyścin, Daraż M (2017) Waste silica as valuable component of extensive green-roof substrate. Pol J Environ Stud 26(2):643-653. https://doi.org/10.15244/ pjoes $/ 64791$

Kutílek M, Nielsen DR (1994) Soil Hydrology. Catena-Verlag, Cremlingen-Destedt

LABO - Bund-/Länderarbeitsgemeinschaft Bodenschutz (2002) Arbeitshilfe für die Qualitätssicherung Kapitel 2: Gewinnung von Boden-, Bodenluft- und Grundwasserproben, Beitrag des Bayerischen Landesamtes für Umweltschutz und des Bayerischen Landesamtes für Wasserwirtschaft, Mai 2002. https://www.labodeutschland.de/documents/labo-arbeitshilfe-qualitaetssicherung-1212-2002_d4c.pdf. Accessed 24 May 2019

Larink O (2008) Nur ein paar Würmer? In: Jopp F, Pieper S (eds) Bodenzoologie und Ökologie: 30 Jahre Umweltforschung an der Freien Universität Berlin. Peter Lang Internationaler Verlag der Wissenschaften, Frankfurt am Main

Lavelle P, Bignell D, Lepage M, Wolters V, Roger P, Ineson P, Heal OW, Dhillion S (1997) Soil function in a changing world: the role of invertebrate ecosystem engineers. Eur J Soil Sci 33(4):159-193

Lavelle P, Decaëns T, Aubert M, Barot S, Bureau F, Margerie P, Mora P, Rossi J-P (2006) Soil invertebrates and ecosystem services. Eur J Soil Biol 42(1):3-15. https://doi.org/10.1016/j.ejsobi.2006.10.002

Milleret R, Le Bayon R-C, Lamy F, Gobat J-M, Boivin P (2009) Impact of roots, mycorrhizas and earthworms on soil physical properties as assessed by shrinkage analysis. J Hydrol 373:499-507. https://doi. org/10.1016/j.jhydrol.2009.05.013

Morel JL, Chenu C, Lorenz K (2015) Ecosystem services provided by soils of urban, industrial, traffic, mining, and military areas (SUITMAs). J Soils Sediments 15(8):1659-1666. https://doi.org/ 10.1007/s11368-014-0926-0

Nehls T, Rokia S, Mekiffer B, Schwartz C, Wessolek G (2013) Contribution of bricks to urban soil properties. J Soils Sediments 13(3):575-584. https://doi.org/10.1007/s11368-012-0559-0

Nehls T, Schwartz C, Kye-Hoon Kim J, Kaupenjohann M, Wessolek G, Morel J-L (2014) Letter to the editors: Phyto-P-Mining-secondary urban green recycles phosphorus from soils constructed of urban wastes. J Soils Sediments 15(8):1667-1674. https://doi.org/10. 1007/s11368-014-1023-0

Peters A, Durner W (2015) SHPFIT 2.0 user's manual. Research report. Institut für Ökologie, Technische Universität, Berlin

Price A, Jones EC, Jefferson F (2015) Vertical greenery systems as a strategy in urban heat island mitigation. Water Air Soil Poll 226: 247. https://doi.org/10.1007/s11270-015-2464-9

Rawski K (2019) Greenery planning for improvement of urban air quality: a review. Poceedings 16:13. https://doi.org/10.3390/ proceedings 2019016013

Rokia S, Séré G, Schwartz C, Deeb M, Fournier F, Nehls T, Dama O, Vidal-Beaudet L (2014) Modelling agronomic properties of Technosols constructed with urban wastes. Waste Manage 34(11): 2155-2162. https://doi.org/10.1016/j.wasman.2013.12.016
Santamouris M, Ban-Weiss G, Osmond P, Paolini R, Synnefa A, Cartalis C, Muscio A, Zinzi M, Morakinyo TE, Ng E, Tan Z, Takebayashi H, Sailor D, Crank P, Taha H, Pisello AL, Rossi F, Zhang J, Kolokotsa D (2018) Progress in urban greenery mitigation science-assessment methodologies advanced technologies and impact on cities. J Civ Eng Manag 24(8):638-671. https://doi.org/10.3846/jcem.2018.6604

Schindler U (1980) Ein Schnellverfahren zur Messung der Wasserleitfähigkeit im teilgesättigten Boden an Stechzylinderproben. Arch Acker Pfl Boden 24(1):1-7

Schindler U, Lischeid G, Müller L (2016) Hydraulic performance of horticultural substrates-impact of substrate composition and ingredients. Horticulturae 3:7. https://doi.org/10.3390/ horticulturae 3010007

Schrader S, Zhang HQ (1997) Earthworm casting: stabilization or destabilization of soil structure? Soil Biol Biochem 29(3-4):469-475. https://doi.org/10.1016/S0038-0717(96)00103-4

Séré G, Schwartz C, Ouvard S, Dauvage C, Ranat J-C, Morel JL (2008) Soil construction: a step for ecological reclamation of derelict land. J Soils Sediments 8(2):130-136. https://doi.org/10.1065/jss2008.03.277

Shuster WD, Subler S, McCoy EL (2002) The influence of earthworm community structure on the distribution and movement of solutes in a chisel-tilled soil. Appl Soil Ecol 21(2):159-167. https://doi.org/10. 1016/S0929-1393(02)00063-X

Smagin AV, Prusak AV (2008) The effect of earthworm coprolites on the soil water retention curve. Eurasian Soil Sci+ 41(6):618-622. https://doi.org/10.1134/S1064229308060069

Smagin AV, Sadovnikova TV, Nzarova TV, Kiryushova AB, Mashika AV, Eremina AM (2002) The effect of organic matter on the waterretention capacity of soils. Eurasian Soil Sci+ 37(3):267-275

Van Schaik L, Palm J, Klaus J, Zehe E, Schröder B (2016) Potential effects of tillage and field borders on within field spatial distribution patterns of earthworms. Agr Ecosyst Environ 228:82-90. https://doi. org/10.1016/j.agee.2016.05.015

VandenBygaart AJ, Fox CA, Fallow DJ, Protz R (2000) Estimating earthworm-influenced soil structure by morphometric image analysis. Soil Sci Soc Am J 64:982-988. https://doi.org/10.2136/ sssaj2000.643982x

Vidal-Beaudet L, Rokia S, Nehls T, Schwartz C (2016) Aggregation and availability of phosphorus in a Technosol constructed from urban wastes. J Soils Sediments 18(2):456-466. https://doi.org/10.1007/ s11368-016-1469-3

Vogel H-J, Cousin I, Ippisch O, Bastian P (2006) The dominant role of structure for solute transport in soil: experimental evidence and modelling of structure and transport in a field experiment. Hydrol Earth Syst Sci 10:495-506. https://doi.org/10.5194/hess-10-4952006

Willaredt M, Nehls T (2020) Investigation of water retention functions of artificial soil-like substrates for a range of mixing ratios of two components. Journal of Soils and Sediments:1-12. https://doi.org/ $10.1007 / \mathrm{s} 11368-020-02727-8$

WRB, IUSS Working Group (2006) World Reference Base for Soil Resources 2006. World Soil Resources Report No. 103. FAO, Rome

Wurst S, Allema B, Duyts H, Van Der Putten WH (2008) Earthworms counterbalance the negative effect of microorganisms on plant diversity and enhance the tolerance of grasses to nematodes. Oikos 117:711-718. https://doi.org/10.1111/j.0030-1299.2008.16333.x

Yilmaz D, Cannavo P, Séré G, Vidal-Beaudet L, Legret M, Damas O, Peyneau P-E (2016) Physical properties of structural soils containing waste materials to achieve urban greening. J Soils Sediments 18(2):442-455. https://doi.org/10.1007/s11368-016-1524-0

Publisher's note Springer Nature remains neutral with regard to jurisdictional claims in published maps and institutional affiliations. 